\title{
Fitting lactation curves of dairy cattle in different types of herds in Tunisia
}

\author{
B. Rekik ${ }^{\mathrm{a}, *}$, A. Ben Gara ${ }^{\mathrm{a}}$, M. Ben Hamouda ${ }^{\mathrm{a}}, \mathrm{H} . \mathrm{Hammami}^{\mathrm{b}}$ \\ ${ }^{a}$ Département des Productions Animales, Ecole Supérieure d'Agriculture de Mateur, 7030, Mateur, Tunisie \\ ${ }^{\mathrm{b}}$ Centre Nationale d'Amélioration Génétique, Sidi Thabet, Ariana, 2020, Tunisie
}

Received 11 April 2002; received in revised form 7 November 2002; accepted 20 December 2002

\begin{abstract}
The incomplete gamma function was used to fit lactation curves of Holstein-Friesian cows in four types of herds in Tunisia. A total of 8640 records were used in the analysis. These included 1269, 637, 239, and 498 first lactation and 2986 , 1441, 650, and 920 second and later lactation records in four herd groups namely investors, state, cooperative, and farmers' herds, respectively. The effects of environmental variables, production sector, herd, parity, first test-day date, calving year, and calving season on the main lactation curve traits were analysed. The factors associated with milk yield at the beginning of lactation and the decreasing phase of the curve, persistency, and peak yield varied significantly $(P<0.01)$ with all variables. The ascending phase of the lactation curve was not affected by parity and calving year, while days in milk until peak depended only on the rank of lactation. The state herds had the lowest peak and total yields. The summer season was unfavourable for milk production. In contrast to first lactation cows, third lactation cows had the highest peak and total yields. Milk yield was highly correlated with peak yield $(r=0.79)$ and was not related to persistency measure.
\end{abstract}

(C) 2003 Elsevier B.V. All rights reserved.

Keywords: Test-day record; Lactation curve; Incomplete gamma; Herd type

\section{Introduction}

Cow population size has substantially increased in the last few years in Tunisia $(455,000$ cows). More than a third $(39 \%)$ of these cows are Holsteins. However, little has been done for the genetic improvement of the cow population. Breeding programmes have been based on $\mathrm{AI}$ and on an official

\footnotetext{
*Corresponding author. Tel.: +216-72-465-565; fax: +216-72468-088.

E-mail address: rekik.boulbaba@iresa.agrinet.tn (B. Rekik).
}

A4 national recording system since the early 1960s. There are 90,000 pure-bred cows registered in the herd book but data have been collected on only 18,000 cows up to the year 2000 .

In the absence of a national genetic evaluation programme, the rationale for a within-herd breeding decision varies with herd owner. There are four types of herds, the state herds (OTD), the cooperative herds (UCPA), the groups of investors' herds (SMVDA), and the farmers' herds. Cows are culled on low milk yield or on an intra-herd cow index in few herds, and proof of foreign bulls are a means to select sires. Yields of milk components and func- 
tional type traits are rarely considered in making breeding decisions.

Cow production during a lactation period of 305 days is subject to variation (Wood, 1972; Norman et al., 1985; Grossman et al., 1986; Bar-Anan et al., 1986; Keown et al., 1986; Ray et al., 1992; Tekerli et al., 2000). Sources of variation are the breed (Shanks et al., 1981; Grossman et al., 1986), environment (Wood, 1972; Ray et al., 1992), feed or water shortage, or different management practices (Wood, 1969; Ray et al., 1992; Tekerli et al., 2000). Various mathematical functions were used to describe lactation curves (Wood, 1967; Schaeffer et al., 1977; Scott et al., 1996; Vargas et al., 2000). The incomplete gamma function (IG) and its variants proved relatively powerful in fitting observed daily yields (Wood, 1967; Scott et al., 1996; Tekerli et al., 2000; Vargas et al., 2000). Fitted lactation curves are useful in directing herd management and extending partial records.

The objectives of this work were to study milk yield production throughout the length of lactation in different types of herds in Tunisia and to determine factors affecting lactation curves.

\section{Materials and methods}

\subsection{Data}

A sample of 18,053 lactation records of 7032 Holstein-Friesian cows was provided by the National Center for Genetic Improvement at Sidi Thabet, Tunis. Data were collected from 1992 to 1999 on 11 herds from four types of herds or production sectors. Data included the cow's identification number, the herd code, the type of herd or production sector, the date of freshening, the lactation number, the test-day date, the test-day milk yield, and the number of times the cow was milked per day.

Editing records resulted in a substantial loss of data. A cow's record was excluded if (1) the lactation number is missing, (2) a cow was controlled less than ten consecutive times during the whole lactation length of 305 days, (3) the interval from the date of freshening to the first test-day date is less than 5 days, and (4) the test-day production is unreasonable (a test-day yield less than $1 \mathrm{~kg}$ or greater than $60 \mathrm{~kg}$ ). After editing, 8640 records remained. These included 1269, 637, 239, and 498 first lactation records and 2986, 1441, 650, and 920 second and older lactation records in the SMVDA, OTD, UCPA, and farmers' herds, respectively.

\subsection{Lactation curves}

The incomplete gamma function (IG) was used to fit lactation curves in the different types of herds. Fitting curves was carried out by the Gauss-Newton algorithm in the NLIN procedure of SAS (1989). Observed daily milk was presented as

$Y_{t}=a t^{b} \mathrm{e}^{-c t}$

where: $Y_{t}$ is the observed milk yield at day $t ; a$ is linked to milk yield at the beginning of lactation, $b$ to the ascending phase before peak yield, and $c$ to the decreasing phase after peak yield.

Persistency, peak yield, and DIM at peak yield (DIMP), were calculated as: $-(b+1) \operatorname{Ln}(c), a(b /$ $c)^{b} \mathrm{e}^{-b}$, and $(b / c)$, respectively (Tekerli et al., 2000).

The effects of production sector, herd, parity, first test-day date, calving year, and calving season were analysed by the following model:

$$
\begin{aligned}
Y_{\mathrm{ijklmn}}= & \mu+S_{i}+H_{j}\left(S_{\mathrm{i}}\right)+P_{k}+\mathrm{CY}_{l}+\mathrm{CS}_{\mathrm{m}} \\
& +b \mathrm{FTD}_{\mathrm{ijklmn}}+e_{\mathrm{ijklmn}}
\end{aligned}
$$

where: $Y_{\mathrm{ijklmn}}=\mathrm{a}$ lactation curve trait based on observation $\mathrm{n}$ in herd $j$ within sector $i(i=1, j=1$, $2 ; i=2, j=1,2,3,4 ; i=3, j=1,2,3 ; i=4, j=1$, $2)$ for parity $k(k=1,2,3,4)$, calving year $l(l=90$, $91, \ldots, 99)$, and calving season $\mathrm{m}(\mathrm{m}=$ fall, winter, spring, and summer); $\mu=$ overall mean; $S=$ effect of sector; $H=$ effect of herd; $P=$ effect of parity; $C Y=$ effect of calving year; $\mathrm{CS}=$ effect of calving season; $b=$ regression coefficient; FTD $=$ first test-day; and $e=$ independent and identically distributed random residuals with expected value 0 and a variance of $\sigma_{\mathrm{e}}^{2}$. Residuals from fitting the model above were used to calculate Pearson phenotypic correlations between the lactation curve traits.

\section{Results and discussion}

\subsection{Fitted lactation curves}

The IG was a good fit for the mean lactation curves across cows in the first and greater parities for 
the four types of herds. The coefficient of determination $(1-$ the ratio of the residual sum of squares to the total sum of squares) from non-linear regression ranged from 92 to $95 \%$.

Individual curves, however, revealed atypical curves (Table 1). The percentage of atypical curves ranged from 15 to $42 \%$. These curves were more frequent in the state (OTD) and cooperative (UCPA) herds than in other herds. Tekerli et al. (2000) reported $26.3 \%$ of atypical curves on a total of 1278 completed lactations.

The IG was also a good fit for typical individual lactation curves. The mean absolute error (Table 1) which is the mean of the predicted test-day yield in a production sector minus the actual test-day yield of a cow in the same test-day and in the same type of herd ranged from 1.5 to $3.2 \mathrm{~kg}$. Those of first lactations were on average lower and were less dispersed than those of later lactations. They are comparable to those found by Scott et al. (1996).
These authors adjusted IG to fat corrected milk produced by 383 cows with a required minimum of $9000 \mathrm{~kg}$ milk per cow.

Lactation curve traits in Table 1 show that first lactation cows produce lower yields than older cows at the beginning of the lactation and were, as expected, more persistent (Tekerli et al., 2000). Multiparous cows on the other hand reach their peak of production earlier in the lactation (5-6th week of lactation) than first parity cows (7-10th week of lactation). The peak yield was greater for older $(23-34 \mathrm{~kg})$ than for primiparous cows $(17-29 \mathrm{~kg})$.

Lactation curves in the four types of herds were clearly different (Figs. 1 and 2). These differences were consistent in first and greater lactations. Cows in the SMVDA herds had the greatest peak yield among all cows in the different production sectors. These cows reached their peak yield later in the lactation than cows in the OTD and UCPA herds but not cows of the farmer group. Cows in the UCPA

Table 1

Lactation curve ${ }^{a}$ traits for primiparous and multiparous Holstein-Friesian cows in state herds (OTD), cooperative herds (UCPA), herds of groups of investors (SMVDA), and in herds of farmers

\begin{tabular}{|c|c|c|c|c|c|c|c|c|c|c|}
\hline \multirow[t]{2}{*}{ Parity } & \multirow[t]{2}{*}{ Sector } & \multirow[t]{2}{*}{$n$} & \multicolumn{6}{|c|}{ Lactation curve trait } & \multirow{2}{*}{$\begin{array}{l}\text { Absolute } \\
\text { error }^{\mathrm{e}}\end{array}$} & \multirow{2}{*}{$\begin{array}{l}\text { Atypical } \\
\text { curves }^{f}\end{array}$} \\
\hline & & & $a$ & $\begin{array}{l}b \\
\left(\times 10^{-2}\right)\end{array}$ & $\begin{array}{l}c \\
\left(\times 10^{-3}\right)\end{array}$ & $\begin{array}{l}\text { Peak }^{\mathrm{b}} \\
(\mathrm{Kg})\end{array}$ & $P^{\mathrm{c}}$ & $\begin{array}{l}\text { DIMP }^{\text {d }} \\
\text { (day) }\end{array}$ & & \\
\hline \multirow[t]{4}{*}{1} & SMVDA & 1042 & $\begin{array}{l}15.28 \\
(7.91)\end{array}$ & $\begin{array}{l}24.96 \\
(0.19)\end{array}$ & $\begin{array}{c}3.57 \\
(0.002)\end{array}$ & $\begin{array}{l}29.31 \\
(4.51)\end{array}$ & $\begin{array}{c}7.17 \\
(0.74)\end{array}$ & $\begin{array}{c}80.70 \\
(285.90)\end{array}$ & $\begin{array}{c}2.01 \\
(1.83)\end{array}$ & 17.88 \\
\hline & OTD & 369 & $\begin{array}{l}13.07 \\
(6.39)\end{array}$ & $\begin{array}{l}23.09 \\
(0.18)\end{array}$ & $\begin{array}{c}3.98 \\
(0.002)\end{array}$ & $\begin{array}{l}23.40 \\
(5.11)\end{array}$ & $\begin{array}{c}6.93 \\
(0.69)\end{array}$ & $\begin{array}{c}58.47 \\
(41.90)\end{array}$ & $\begin{array}{c}2.05 \\
(1.82)\end{array}$ & 34.80 \\
\hline & UCPA & 118 & $\begin{array}{l}10.47 \\
(5.59)\end{array}$ & $\begin{array}{l}21.44 \\
(0.20)\end{array}$ & $\begin{array}{c}3.50 \\
(0.002)\end{array}$ & $\begin{array}{l}17.47 \\
(4.48)\end{array}$ & $\begin{array}{c}7.00 \\
(0.81)\end{array}$ & $\begin{array}{c}61.50 \\
(46.37)\end{array}$ & $\begin{array}{c}1.45 \\
(1.38)\end{array}$ & $\begin{array}{l}41.80 \\
27.7\end{array}$ \\
\hline & Farmer & 315 & $\begin{array}{l}11.75 \\
(6.37)\end{array}$ & $\begin{array}{l}26.92 \\
(0.21)\end{array}$ & $\begin{array}{c}3.39 \\
(0.002)\end{array}$ & $\begin{array}{l}24.39 \\
(4.16)\end{array}$ & $\begin{array}{c}7.41 \\
(0.83)\end{array}$ & $\begin{array}{c}91.90 \\
(92.90)\end{array}$ & $\begin{array}{c}1.90 \\
(1.72)\end{array}$ & \\
\hline \multirow[t]{4}{*}{$\geq 2$} & SMVDA & 1692 & $\begin{array}{l}20.21 \\
(8.85)\end{array}$ & $\begin{array}{l}22.30 \\
(0.16)\end{array}$ & $\begin{array}{c}4.70 \\
(0.001)\end{array}$ & $\begin{array}{l}34.66 \\
(5.37)\end{array}$ & $\begin{array}{c}6.61 \\
(0.56)\end{array}$ & $\begin{array}{c}44.85 \\
(21.55)\end{array}$ & $\begin{array}{c}3.24 \\
(2.81)\end{array}$ & 14.90 \\
\hline & OTD & 585 & $\begin{array}{l}18.04 \\
(7.89)\end{array}$ & $\begin{array}{l}19.30 \\
(0.16)\end{array}$ & $\begin{array}{c}4.57 \\
(0.002)\end{array}$ & $\begin{array}{l}27.95 \\
(5.57)\end{array}$ & $\begin{array}{c}6.50 \\
(0.57)\end{array}$ & $\begin{array}{c}39.34 \\
(23.81)\end{array}$ & $\begin{array}{c}2.68 \\
(2.40)\end{array}$ & 26.30 \\
\hline & UCPA & 282 & $\begin{array}{l}16.46 \\
(5.88)\end{array}$ & $\begin{array}{l}15.40 \\
(0.15)\end{array}$ & $\begin{array}{c}3.93 \\
(0.002)\end{array}$ & $\begin{array}{l}23.28 \\
(3.94)\end{array}$ & $\begin{array}{c}6.44 \\
(0.55)\end{array}$ & $\begin{array}{c}36.50 \\
(21.52)\end{array}$ & $\begin{array}{c}2.20 \\
(1.93)\end{array}$ & 29.30 \\
\hline & Farmer & 458 & $\begin{array}{l}16.08 \\
(6.99)\end{array}$ & $\begin{array}{l}21.93 \\
(0.15)\end{array}$ & $\begin{array}{c}4.01 \\
(0.002)\end{array}$ & $\begin{array}{l}28.48 \\
(4.83)\end{array}$ & $\begin{array}{c}6.81 \\
(0.60)\end{array}$ & $\begin{array}{c}55.57 \\
(35.48)\end{array}$ & $\begin{array}{c}2.81 \\
(2.51)\end{array}$ & 18.00 \\
\hline
\end{tabular}

(): Standard deviation.

${ }^{\mathrm{a}}$ Modeled as: $Y_{t}=a t^{b} \mathrm{e}^{-c t}$, where $Y_{t}=$ milk yield on day $t, a=$ a factor to represent yield at the beginning of lactation, and $b$ and $c$ are factors associated with the ascending and decreasing phases of the lactation curve.

${ }^{\mathrm{b}}$ Peak yield calculated as: $a(b / c)^{b} \mathrm{e}^{-b}$.

${ }^{\mathrm{c}}$ Persistency calculated as: $-(b+1)^{*} \operatorname{Ln}(c)$.

${ }^{\mathrm{d}}$ DIMP: DIM at peak yield calculated as: $(b / c)$.

${ }^{\mathrm{e}}$ Absolute error in $\mathrm{kg}$. The error is the predicted test-day yield in a herd type minus the actual yield of a cow in the same test-day and the same herd.

${ }^{\mathrm{f}}$ Percentage atypical curves with either $a$ or $b$ is negative. 


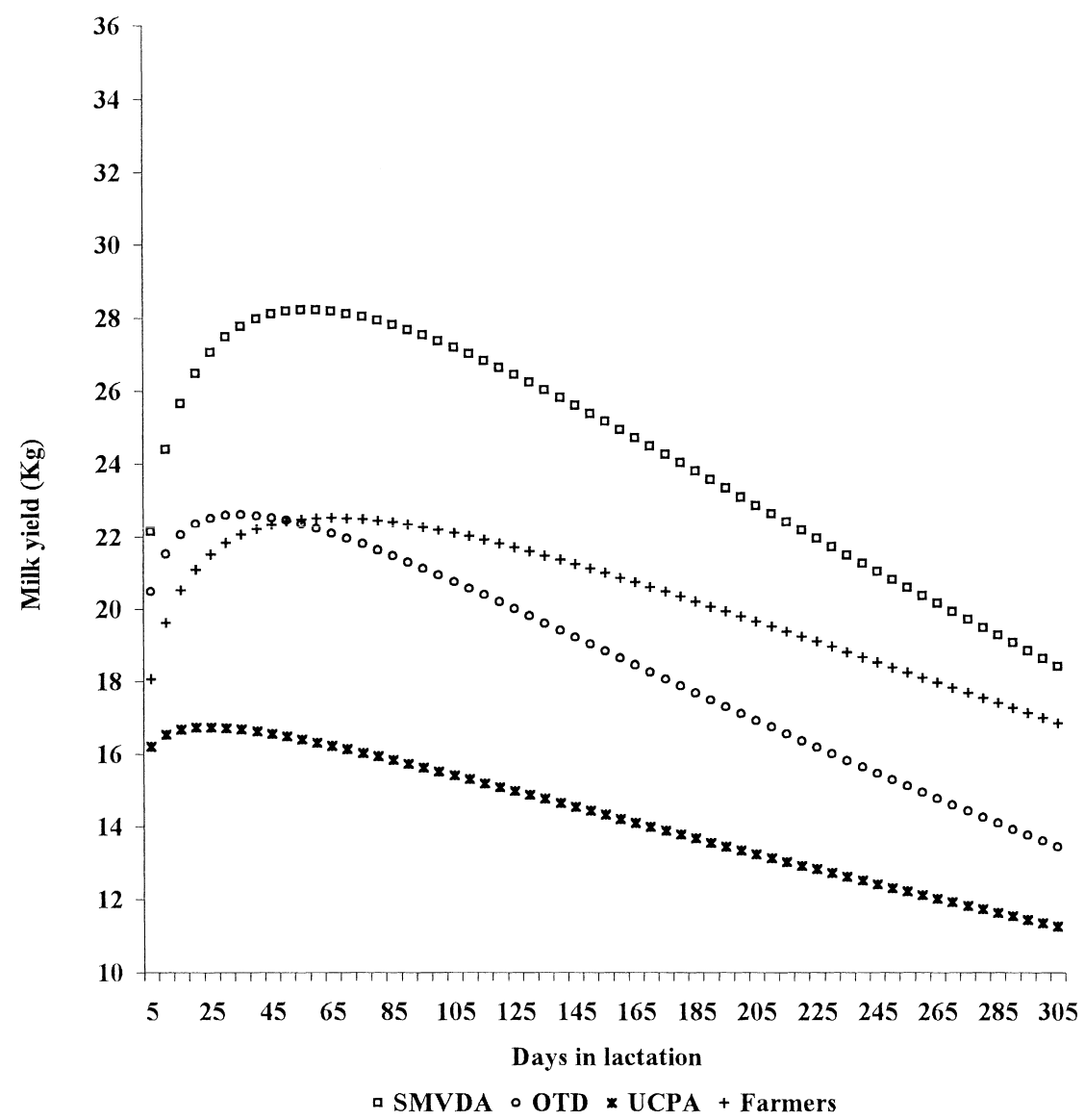

Fig. 1. Fitted mean curves of primiparous lactation records in state herds (OTD), cooperative herds (UCPA), in herds of group of investors (SMVDA), and in herds of farmers.

herds had the flattest curves, comparable to those of genetically poor cows. It appears that UCPA herds have the poorest management practices among all production sectors.

\subsection{Factors affecting the shape of lactation curves}

The ANOVA mean squares of production sector, herd, parity, calving year, calving season, and DIM at first test-day on lactation curve traits are shown in Table 2. The least square means of level effects and the coefficient of regression on DIM at first test-day are shown in Table 3. All effects were highly significant $(P<0.01)$ on $a, c$, peak yield, persistency, and total yield through 305 DIM, while $b$ seemed not to depend on the lactation number and the calving year. DIM at peak yield varied only with parity. Holstein-Friesian cows seemed to reach the highest total peak yields in the third lactation in Tunisia. The coefficient of determination ranged from 0.02 for the trait DIM at peak yield to 0.51 for the peak yield. These results are similar to previous findings (Schneeberger, 1981; Tekerli et al., 2000). The high level of significance of model effects on most of the lactation curve traits suggests major differences in management between and within production sectors and also important annual climate changes in Tunisia.

Total and peak yields were the lowest for cows calving in the summer season when feeding resources are limited and the heat stress effect is important in Tunisia. Lactation curve characteristics 


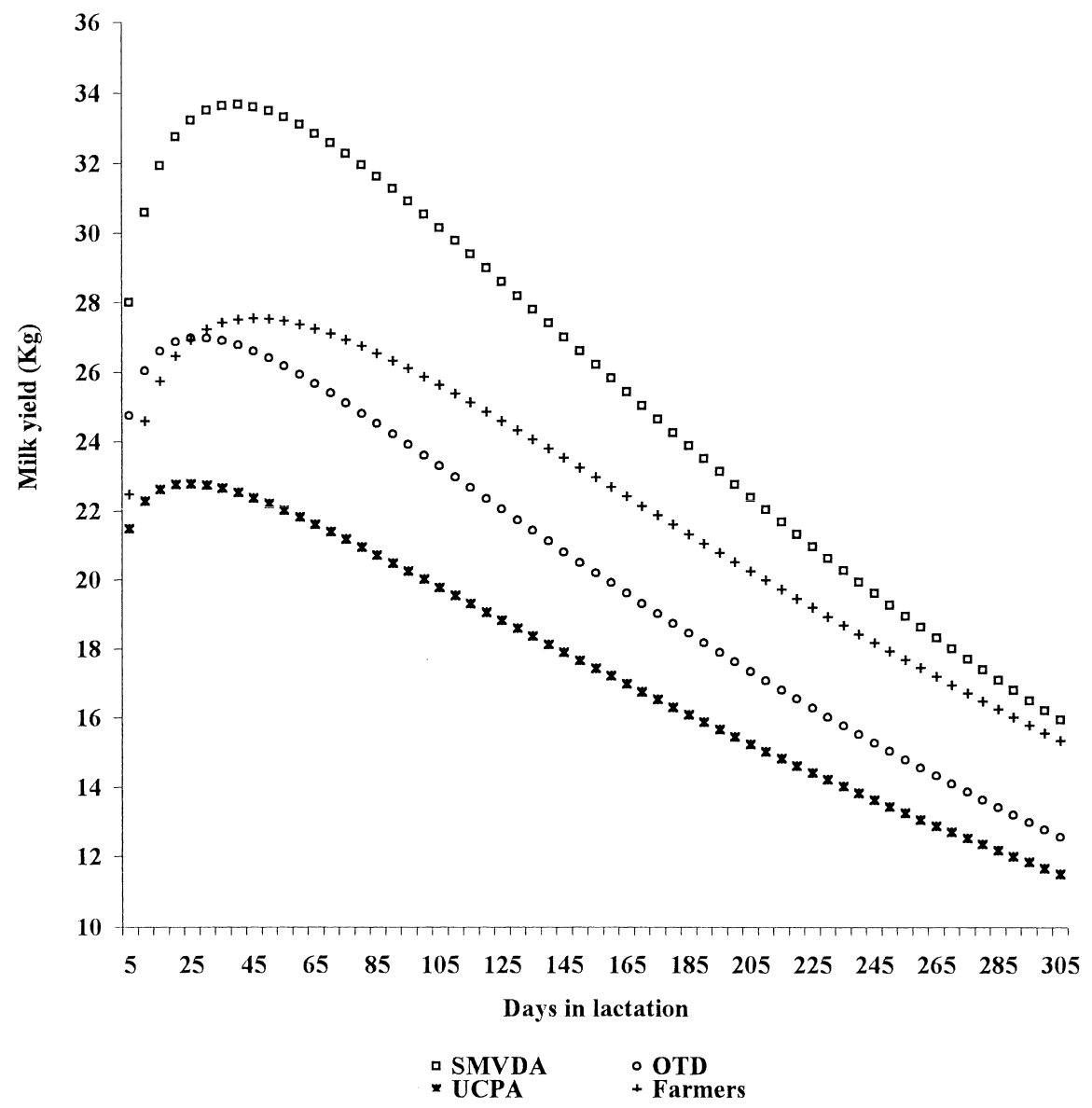

Fig. 2. Fitted mean curves of multiparous lactation records in state herds (OTD), cooperative herds (UCPA), in herds of group of investors (SMVDA), and in herds of farmers.

of first lactation cows are identical to those reported in earlier research (Keown et al., 1986; Tekerli et al., 2000). First lactation cows have the lowest total and peak yields but the highest DIM at peak and persistency. On the other hand, this data show that third parity cows have the highest total and peak yields (Table 3 ).

The relationships among the main lactation curve traits agree with earlier findings (Keown et al., 1986; Tekerli et al., 2000). The phenotypic correlations in this work (Table 4) show that cows producing at high level yield in the beginning of the lactation are likely to have a low rate of increase (negative correlation of $a$ with $b$ ) until peak yield. They are also the least persistent. However, these cows seem to yield a high 305 DIM milk. Positive correlations of $b$ with $c$, and of $b$ and $c$ with persistency imply that cows with a higher rate of increase until the peak and consequently higher rate of decrease after the peak are the most persistent. However, this work provides no evident relation of persistency with total yield in 305 DIM. Finally, cows with the highest peak yield are likely to produce the highest total yield.

\section{Conclusion}

In addition to the most common environmental variables, herd, parity, calving year, calving season, and DIM at first test day, the effect of production sector is highly significant $(P<0.01)$ on the main 
Table 2

Mean squares of variables from the analysis of variance of lactation curve ${ }^{a}$ traits for Holstein-Friesian cows in Tunisia

\begin{tabular}{|c|c|c|c|c|c|c|c|c|}
\hline \multirow[t]{2}{*}{ Variable } & \multirow[t]{2}{*}{$\mathrm{df}$} & \multicolumn{7}{|c|}{ Lactation curve traits } \\
\hline & & $a$ & $b$ & $\begin{array}{l}c \\
\left(\times 10^{-3}\right)\end{array}$ & Peak $^{\text {b }}$ & $\begin{array}{l}\text { DIMP }^{\mathrm{c}} \\
\left(\times 10^{4}\right)\end{array}$ & $P^{\mathrm{d}}$ & $\begin{array}{l}Y_{305}{ }^{\mathrm{e}} \\
\left(\times 10^{7}\right)\end{array}$ \\
\hline Sector & 3 & $5843.7 * *$ & $0.25 * *$ & $0.28 * *$ & $26917.2 * *$ & 4.18 & $9.35 * *$ & $161.31^{* *}$ \\
\hline Herd(sector) & 7 & $1123.9 * *$ & $0.10 * *$ & $0.34 * *$ & $2014.9 * *$ & 0.32 & $4.65^{* *}$ & $7.48^{* *}$ \\
\hline Parity & 3 & $7993.7 * *$ & 0.06 & $5.43 * *$ & $13633.3 * *$ & $29.36 * *$ & $72.24 * *$ & $20.51 * *$ \\
\hline Calving year & 9 & $221.7 * *$ & 0.02 & $0.18 * *$ & $583.9 * *$ & 1.76 & $0.97 *$ & $2.36^{* *}$ \\
\hline Calving season & 3 & $296.8 * *$ & $0.33^{* *}$ & $0.67 * *$ & $368.9 * *$ & 4.23 & $3.94 * *$ & $1.03 * *$ \\
\hline DIM at first test day & 1 & $14427.6^{* *}$ & $12.19 * *$ & $7.11 * *$ & $560.7 * *$ & 3.35 & $99.39 * *$ & $1.30^{* *}$ \\
\hline Residual & 4834 & 69.7 & 0.04 & 0.05 & 25.6 & 1.86 & 0.49 & 0.14 \\
\hline$R^{2}$ & $\ldots$ & 0.16 & 0.08 & 0.12 & 0.51 & 0.02 & 0.15 & 0.45 \\
\hline
\end{tabular}

$* P<0.05$.

** $P<0.01$.

${ }^{\text {a }}$ Modeled as: $Y_{t}=a t^{b} \mathrm{e}^{-c t}$, where $Y_{t}=$ milk yield on day $t, a=$ a factor to represent yield at the beginning of lactation, and $b$ and $c$ are factors associated with the ascending and decreasing phases of the lactation curve.

${ }^{\mathrm{b}}$ Peak yield calculated as: $a(b / c){ }^{b} \mathrm{e}^{-b}$.

${ }^{\mathrm{c}}$ DIMP: DIM at peak yield calculated as: $(b / c)$.

${ }^{\mathrm{d}}$ Persistency calculated as: $-(b+1) * \operatorname{Ln}(c)$.

e Total milk yield in 305 DIM.

Table 3

Least square means for variable levels' effects and linear regression coefficient for lactation curve ${ }^{\mathrm{a}}$ traits of Holstein-Friesian cows in Tunisia

\begin{tabular}{|c|c|c|c|c|c|c|c|c|}
\hline \multirow[t]{2}{*}{ Variable } & \multirow[t]{2}{*}{$n$} & \multicolumn{7}{|c|}{ Lactation curve traits } \\
\hline & & $a$ & $b$ & $c$ & Peak $^{\text {b }}$ & $P^{\mathrm{c}}$ & DIMP $^{d}$ & $Y_{305}{ }^{\mathrm{e}}$ \\
\hline \multicolumn{9}{|l|}{ Sector } \\
\hline SMVDA & 2734 & $19.13^{\mathrm{a}}$ & $0.24^{\mathrm{a}}$ & $4.36^{\mathrm{a}}$ & $34.92^{\mathrm{a}}$ & $6.83^{\mathrm{a}}$ & $56.85^{\mathrm{a}}$ & $8337^{\mathrm{a}}$ \\
\hline OTD & 954 & $15.15^{\mathrm{b}}$ & $0.23^{\mathrm{a}}$ & $4.48^{\mathrm{a}}$ & $26.06^{\mathrm{b}}$ & $6.75^{b}$ & $46.55^{\mathrm{ab}}$ & $6057^{\mathrm{b}}$ \\
\hline UCPA & 400 & $14.09^{c}$ & $0.20^{\mathrm{b}}$ & $3.98^{\mathrm{b}}$ & $22.79^{\mathrm{c}}$ & $6.74^{\mathrm{b}}$ & $49.06^{\mathrm{ab}}$ & $5456^{\mathrm{C}}$ \\
\hline Farmer & 773 & $15.40^{\mathrm{b}}$ & $0.26^{\mathrm{c}}$ & $4.17^{\mathrm{b}}$ & $29.26^{\mathrm{d}}$ & $7.00^{\mathrm{c}}$ & $63.66^{\mathrm{ac}}$ & $7071^{\circ}$ \\
\hline \multicolumn{9}{|l|}{ Parity } \\
\hline 1 & 1844 & $12.49^{\mathrm{a}}$ & $0.24^{\mathrm{a}}$ & $3.33^{\mathrm{a}}$ & $23.73^{\mathrm{a}}$ & $7.16^{\mathrm{a}}$ & $75.31^{\mathrm{a}}$ & $6192^{2}$ \\
\hline 2 & 1346 & $16.17^{\mathrm{b}}$ & $0.23^{\mathrm{a}}$ & $4.31^{\mathrm{b}}$ & $28.31^{\mathrm{b}}$ & $6.77^{\mathrm{b}}$ & $49.05^{\mathrm{b}}$ & $6715^{b}$ \\
\hline 3 & 916 & $18.13^{\mathrm{c}}$ & $0.23^{\mathrm{a}}$ & $4.55^{\mathrm{c}}$ & $30.83^{\mathrm{c}}$ & $6.68^{\mathrm{c}}$ & $44.96^{\mathrm{b}}$ & $7120^{\circ}$ \\
\hline 4 & 755 & $16.93^{\mathrm{b}}$ & $0.24^{\mathrm{a}}$ & $4.81^{\mathrm{d}}$ & $30.17^{\mathrm{d}}$ & $6.71^{\mathrm{c}}$ & $46.84^{\mathrm{b}}$ & $6897^{\circ}$ \\
\hline \multicolumn{9}{|l|}{ Season } \\
\hline Fall & 1043 & $16.13^{\mathrm{a}}$ & $0.22^{\mathrm{a}}$ & $3.97^{\mathrm{a}}$ & $28.11^{\mathrm{a}}$ & $6.88^{\mathrm{a}}$ & $56.51^{\mathrm{a}}$ & $6790^{\mathrm{a}}$ \\
\hline Winter & 1281 & $15.25^{\mathrm{b}}$ & $0.26^{\mathrm{b}}$ & $4.50^{\mathrm{b}}$ & $28.68^{\mathrm{b}}$ & $6.87^{\mathrm{a}}$ & $60.34^{\mathrm{ab}}$ & $6771^{\mathrm{a}}$ \\
\hline Spring & 1279 & $16.39^{\mathrm{a}}$ & $0.23^{\mathrm{a}}$ & $4.40^{\mathrm{b}}$ & $28.71^{\mathrm{b}}$ & $6.76^{\mathrm{b}}$ & $46.61^{\mathrm{ac}}$ & $6769^{a}$ \\
\hline Summer & 1258 & $15.94^{\mathrm{a}}$ & $0.22^{\mathrm{a}}$ & $4.12^{\mathrm{a}}$ & $27.54^{\mathrm{c}}$ & $6.81^{\mathrm{c}}$ & $52.70^{\mathrm{a}}$ & $6593^{\mathrm{b}}$ \\
\hline DIM at first test-day & & $-0.18^{* *}$ & $0.01 * *$ & $0.04 * *$ & $-0.04 * *$ & $0.02 * *$ & 0.28 & $3.64 *$ \\
\hline
\end{tabular}

\footnotetext{
a, b, c, d Means of variable levels with different superscripts for each lactation curve trait are significantly different $(P<0.05)$.

$* P<0.05$.

$* * P<0.01$.

${ }^{\mathrm{a}}$ Modeled as: $Y_{t}=a t^{b} \mathrm{e}^{-c t}$, where $Y_{t}=$ milk yield on day $t, a=\mathrm{a}$ factor to represent yield at the beginning of lactation, and $b$ and $c$ are factors associated with the ascending and decreasing phases of the lactation curve.

${ }^{\mathrm{b}}$ Peak yield calculated as: $a(b / c)^{b} \mathrm{e}^{-b}$.

${ }^{\mathrm{c}}$ Persistency calculated as: $-(b+1) * \operatorname{Ln}(c)$.

${ }^{\mathrm{d}}$ DIMP: DIM at peak yield calculated as: $(b / c)$.

${ }^{\mathrm{e}}$ Total milk yield in 305 DIM.
} 
Table 4

Phenotypic correlations between lactation curve ${ }^{a}$ traits of Holstein-Friesian cows in Tunisia

\begin{tabular}{|c|c|c|c|c|c|c|}
\hline Trait & $b$ & $c$ & Peak $^{\text {b }}$ & DIMP $^{c}$ & Persistency $^{\mathrm{d}}$ & $Y_{305}{ }^{\mathrm{e}}$ \\
\hline$a$ & $-0.80 * *$ & $-0.56^{* *}$ & $0.41 * *$ & $-0.16^{* *}$ & $-0.69 * *$ & $0.34 * *$ \\
\hline$b$ & & $0.79 * *$ & $-0.06 * *$ & $0.12 * *$ & $0.74 * *$ & $-0.17 * *$ \\
\hline$c$ & & & $0.14 * *$ & -0.01 & $0.23 * *$ & $-0.29 * *$ \\
\hline Peak & & & & 0.01 & $-0.23 * *$ & $0.79 * *$ \\
\hline DIMP & & & & & $0.33 * *$ & 0.02 \\
\hline Persistency & & & & & & -0.00 \\
\hline
\end{tabular}

$* P<0.05$.

$* * P<0.01$

${ }^{a}$ Modeled as: $Y_{t}=a t^{b} \mathrm{e}^{-c t}$, where $Y_{t}=$ milk yield on day $t, a=$ a factor to represent yield at the beginning of lactation, and $b$ and $c$ are factors associated with the ascending and decreasing phases of the lactation curve.

${ }^{\mathrm{b}}$ Peak yield calculated as: $a(b / c)^{b} \mathrm{e}^{-b}$.

${ }^{\mathrm{c}}$ DIMP: DIM at peak yield calculated as: $(b / c)$.

${ }^{\mathrm{d}}$ Persistency calculated as: $-(b+1) * \operatorname{Ln}(c)$.

${ }^{\mathrm{e}}$ Total milk yield in 305 DIM.

lactation curve traits in Tunisia. Each type of herd seems to have its proper management and breeding decisions. Cows in the SMVDA herds had the highest total and peak yields, while cows in the UCPA herds seem not to produce milk up to their potential. The summer season is the least favourable for milk production. In contrast to first lactation cows, third lactation cows had the highest peak and total yields. Peak yield is highly correlated with total yield. Persistency as measured in this work was not related to the total 305 DIM yield. Peak yield might be used to cull cows early in the lactation, however, we should take into account secondary traits (health traits) and feed consumption.

\section{Acknowledgements}

The authors are grateful to the National Centre for Genetic Improvement at Sidi Thabet for providing the data.

\section{References}

Bar-Anan, R., Weller, J.I., Wiggans, G.R., Osterkorn, K., 1986. Prediction of annualised lactation yield from partial lactations. J. Dairy Sci. 69, 1897-1903.

Grossman, M., Kuck, A.L., Norton, H.W., 1986. Lactation curves of pure-bred and crossbred dairy cattle. J. Dairy Sci. 69, 195-203.
Keown, J.F., Everett, R.W., Empet, N.B., Wadell, L.H., 1986. Lactation curves. J. Dairy Sci. 69, 769-781.

Norman, H.D., Dickinson, F.N., Wright, J.R., 1985. Merit of extending completed records of less than 305 days. J. Dairy Sci. 68, 2646-2654.

Ray, D.E., Halbach, T.J., Armstrong, D.V., 1992. Season and lactation effects on milk production and reproduction of dairy cattle in Arizona. J. Dairy Sci. 75, 2976-2983.

SAS User's Guide, Version 6.10 for windows. 1989. SAS Institute Inc., Cary, NC.

Schneeberger, M., 1981. Inheritance of lactation curve in Swiss Brown cattle. J. Dairy Sci. 64, 475-483.

Scott, T.A., Yandell, B., Zepeda, L., Shaver, R.D., Smith, T.T., 1996. Use of lactation curves for analysis of milk production data. J. Dairy Sci. 79, 1885-1894.

Schaeffer, L.R., Minder, C.E., McMillan, I., Burnside, E.B., 1977. Non-linear techniques for predicting 305-day lactation production of Holsteins and Jerseys. J. Dairy Sci. 60, 1636-1644.

Shanks, R.D., Berger, P.J., Freeman, A.E., Dickinson, F.N., 1981. Genetic aspects of lactation curves. J. Dairy Sci. 64, 18521860.

Tekerli, M., Akinci, Z., Dogan, I., Ackan, A., 2000. Factors affecting the shape of lactation curves of Holstein cows from the Balikesir province of Turkey. J. Dairy Sci. 83, 1381-1386.

Vargas, B., Koops, W.J., Herrero, M., Van Arendonk, J.A.M., 2000. Modelling extended lactations of dairy cows. J. Dairy Sci. 83, 1371-1380.

Wood, P.D.P., 1967. Algebraic model of the lactation curve in cattle. Nature (London) 216, 164-165.

Wood, P.D.P., 1969. Factors affecting the shape of the lactation curve in cattle. Anim. Prod. 11, 307-316.

Wood, P.D.P., 1972. A note on seasonal fluctuations in milk production. Anim. Prod. 15, 89-92. 